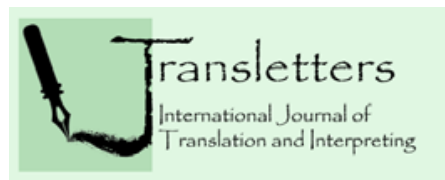

\title{
The Possible Reasons for Misunderstanding the Meanings of Puns in the Holy Quran from Arabic into English
}

\author{
Mohammed H. Al Aqad, Thabet Abu-Alhaj \\ University of Malaya
}

Received: 28/03/2018

Accepted: 23/04/2018

\section{Abstract}

The Holy Quran is the central point of Islam and is the link, which connects humanity (the creation) with Allah (the creator). Translation of the Qur'an is still a problematic issue for each translator in the Islamic theology due to the Quran has numerous Islamic terms/words that hold multiple or double meaning, which causes problems in translation. These problems are due to the dissimilar translations of puns (tawriyah) and the misinterpretations between the intended meanings of puns with their inherent notions, which could result in a certain amount of ambiguity. Translators and interpreters of the Qur'an face numerous difficulties that make their translation an impossible task to be able to cater for this fact in their translations, consequently; they end up translating the superficial sense, which leads to tremendous loss of semantics, and rhetoric features. This research deals with the challenges of translating the meanings of puns (tawriyah) meanings from the Quran into English. The study examines the Quranic text and its two widespread English translations by Yusuf Ali (2014), Pickthall (1993). The research corpus is based on several verses (Ayat) selected from the Holy Quran. The study employs Delabastita's (1996) typology of horizontal puns in order to apply it on the Holy Quran and identify the types of puns employed in the Quranic text. The objectives of the study are to determine the types of English puns that were produced by the two translators in the Quranic text according to Delabastita's (1993) typology, to identify causes for misunderstanding the meanings of puns in the Holy Quran from Arabic into English.

\section{Key Words}

The Holy Quran, puns misunderstanding, Delabastita strategies, reasons for misinterpreting the Quran

\section{$\cos 80$}




\section{Introduction}

The pun, also called paronomasia, is a form of wordplay that exploits the multiple meanings of a term, or of similar-sounding words, for an intended humorous or rhetorical effect (Wikipedia). Puns observed as in-jokes or idiomatic structures, as their usage and meaning is specific to a certain language and its culture. Wordplay is a literary technique in which the nature of the words used themselves become part of the subject of the work (e.g. Puns, spoonerisms, polysemy and paronomasia). Wordplay is the general name for the several textual phenomena in which structural features of the languages are utilized in order to bring about a communicatively significant confrontation of two (or more) linguistic features with more or less similar forms and more or less different senses. Whether serious or comical, wordplay creates linguistic problems of translatability because different languages have different meaning (Delabastita 2004: 601).

Delabastita (1993, p. 191) has presented the following translation strategies for wordplay (pun) which the researcher will apply in the current study:

1. Pun to pun: the source text pun has translated by a target language pun, which may be more or less different from the original wordplay in terms of formal structure, semantic structure, or lexical function.

2. Pun to non-pun: the pun has rendered by a non-punning phrase, which may salvage both senses of wordplay but in a non-punning conjunction, or select one of the senses at the cost of suppressing the other; of course, it may also occur that both components of the pun have translated beyond recognition.

3. Pun to related rhetorical device: the pun has replaced by some wordplay related rhetorical device (repetition, alliteration, rhyme, referential vagueness, irony, paradox, etc.) which also aims to recapture the effect of the source text pun.

4. Pun to zero: the portion of text containing the pun has simply omitted.

5. Pun $S T=$ pun TT: the translator reproduces the source-text pun and possibly its immediate environment in its original formulation, i.e. without actually translating it such as the word (Quran, Hajj and Zakat) might be used in both ST and TT alike.

6. Non pun to pun: the translator introduces a pun in textual positions where the original text has no pun, by way of compensation to make up for source text puns lost elsewhere, or for any other reason.

7. Editorial techniques: explanatory footnotes or endnotes, comments provided in translator's forewords, the anthological presentation of different, 
supposedly complementary solutions to the same source text problem, and so forth.

The Holy Quran uses many linguistic and rhetorical features that result in an effective and sublime style. This use of linguistic and rhetorical features encounters the translators of the Holy Quran, especially when translating such literary terms metaphor, pun, irony, polysemy, paronomasia, synonymy and spoonerisms. This study shed lights on the stylistic and linguistic problems in rendering the Holy Quran into English.

According to (Abobaker Ali, M Alsaleh \& others, 2012) Rendering the Holy Quran from Arabic into other languages is escorted by several linguistic challenges, as no two languages are equal either in the meaning given to the corresponding signs or in the ways in which such signs are categorized in phrases and sentences. Lexical, syntactic and semantic problems ascend when transferring the meaning of the Holy Quran into English due to the unlike language system between English and Arabic.

One of the main lexical and semantic problems faced by the translator of the Holy Quran is the lack of equivalence or the absence of the equivalent of some Islamic or Quranic terms. These terms have no direct equivalent in English, forcing the translator to transfer them in a communicative manner.

\section{Theoretical Framework}

"Quranic context is characterized by syntactic constructions, which display fascinating linguistic architecture where the permutation of constituents plays a significant role in the interior and exterior linguistic decoration of the construction" (Abdul-Raof, 2006, p. 68). The great impression and sublimity of the Holy Quran have based on employment of stylistic and figurative devices in this masterpiece of rhetoric. These rhetorical and linguistic devices, which are not only syntactic but also semantic and phonetic, such as irony, metaphor, parallelism, linguistic deviation, pun, rhyme, polysemy, synonymy, and metonymy challenge translators of the Holy Quran.

The Quranic text is built up of several stylistic, linguistic and rhetorical elements that make it hang together. Non-Quranic texts in Arabic display mostly linguistic cohesive elements; the Quran, however, displays abundantly both linguistic as well as rhetorical cohesive elements, which cannot be divorced from each other; in other words, they are bedrock of the Quranic texture and the major vehicle for the attainment of perfection and sublimity in style, on the one hand, and are a unique and effective technique that can eliminate the occurrence of a ponderous and laboured style, on the other; it is 
the-se intricate elements which make Quranic discourse like a "single ingot" and a harmonious tune (Abdul-Raof, 2006, p.70). English and Arabic have two different language systems and different word arrangement, which consequence a challenge of cohesion due to the word order discrepancies in the language systems, which therefore affect the translation of pun as stated in (Hijjo and Kadhim, 2017).

Since there are, no two languages or more are equal neither in the equivalence nor in their categorization in the phrase and sentence, hence; a translator of the literary text may encounter many linguistic problems while transferring the source text into another language. All of these hitches occur certainly in the process of translating the Holy Quran into English (Ali, Brakhw, Nordin, \& Islam, 2012).

\section{Definition of Pun in English}

According to Delabastita (1987, p. 128): wordplay is the general name for the various textual phenomena in which structural features of the languages used are exploited in order to bring about a communicatively significant confrontation of two (or more) linguistic structures with more or less similar forms and more or less different meanings. In this definition, it is stated "the pun is based on the confrontation of linguistic forms that are formally similar, but have different meanings" (Delabastita, 1993, p. 58).

Also, in this definition, according to Sanderson (2009):

The formal similarity has manifested in terms of spelling and pronunciation. It is therefore the confrontation of similar forms and dissimilar meanings between linguistic structures that gives rise to ambiguity. This means that ambiguity arises because words that look and/or sound the same but have different meanings exploited in such a manner that an additional semantic layer added to the otherwise stable relationship between signifier and signified (p. 123).

\section{Categorization of Pun in English}

Several criteria has attended to carry out a categorization of wordplay. Delabastita, (1993) applied a formal criteria and a linguistic phenomenon as basis of his classification. According to the formal criterion, a distinction has drawn between two types of puns, namely vertical pun and horizontal pun, in this study the researcher will discuss only the horizontal puns. Delabastita asserted that different types of horizontal pun are Homophony, homography, paronymy, and homonymy (lbid). He explained the puns as the follow: 
Homophonic pun based on the exploitation of word pairs, which sound alike, but are different in spelling. An example of such word pair is tale and tail.

Homographic pun indicates two expressions, spelt the same way and creating graphemic ambiguity. A word of the same spelling as another but derived from a different root and having a different meaning (e.g., to wind and the wind; to present and a present or bow (the front part of a ship), bow (to bend), and bow (a decorative knot)).

Paronymic pun exploits words that have slight differences in both spelling and pronunciation. An example of such a word pair is adding in Salt/insult to injury.

Homonymic pun is comprised of words that are identical both in spelling and in pronunciation. The words have different meaning, though. An example is the word bear, which can be a verb (to carry) or a noun (the animal).

Syntactic pun constituted by a statement, which can be analyzed syntactically in at least two different ways.

Morphological pun composed by words, which can be related to other words by means of morphological devices such as derivation or compounding.

\section{Definition of Pun in Arabic}

Originally, the Arabic rhetorical term "التورية" [at-Tawriyyah, lit.pun] is derived from the Arabic statement "وَرَرَّيتُ الخبرَ أَو الثَى "Twarraytu al-khabara aw alshaya] which literally means, "I have hidden the news or the thing in order not to be known by others". Technically speaking, it means intentional hiding a very subtle sense of a spoken or written text and makes it difficult or impossible to be completely grasped by certain people in an audience (AlJawhari, 1956:2523). This interpretation has clearly supported by a number of Quranic texts such as:

(1) Surah “An-Nahl, The Bee”, ayah 59.

.

He hides Himself with shame from his people, Because of the bad news he has had.

(2) Surah "Al-Ma'idah, The Table" ayah 31.

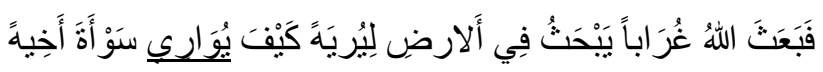

Then God sent a raven, which scratched the ground in order to show him how to hide the nakedness of his brother.

Rhetorically speaking, the Arabic term "توريةة and its English counterpart "pun" both refer to a figure of speech which is rich in its linguistic (syntactic, semantic, morphological, and lexical) content. Arab rhetoricians have seen pun 
as a fundamental figure of speech for its rhetorical force in texts. It has been used as a rhetorical device and played an essential role in both poetry and prose since the pre-Islamic era. It has frequently used in the Glorious Quran as well as in the Prophetic Tradition to express certain semantic values in various textual structures. Abd Ut-Tawwab (1967) defined pun "At-Tawriyyah" as:

A word which has two meanings: Adjacent with clear reference, and far with hidden reference. The latter is often intended. The faster that comes to the hearer's mind is the approximate meaning. The speaker aims at the far meaning but uses the near one to cover it (p. 293).

Briefly speaking, English rhetoricians mostly concentrate on a number of phonologically oriented rhetorical figures, which have homophonic, homographic and / or homonymic nature, and consider them as major types of pun, while the Arab rhetoricians treat these western puns as types of paronomasia, therefore they are seen as non- puns in Arabic rhetoric.

\section{Categorization of Pun in Arabic}

According to most Arabic rhetoricians (al-Qazwini, 1975:p.499; Al-Satiq, 1971; As-Safadi, 1987; Ibn abi Rabiaah, 1935; Al-Jawhari, 1956) there are four main types of Arabic puns which are governed and controlled by a logico-semantic contextual framework which determines both their immediate and far-fetched meanings. According to this criterion, pun is divided into:

\section{(1) Tawriyyah al-Mujaradah (stripped-off pun)}

In this type of pun, devoid from duo; the lexical requirements of the punned with (al-muwarra bihid المواري ), which normally represents the immediate meaning, and the requirements of the punned to (al-muwarra anhu المواري عنه المئ (a), which are represents by the remote meaning. Consider the following Quranic text:

Surah "Taha", ayah 5.

$$
\text { الرّحمنُ على العرشِ إِستويُ }
$$

The ever-merciful, established on the throne (of authority).

$$
\text { Tawriyyah al-Murashabah (strengthened pun) }
$$


In this type of pun, there must be a lexical requirement for the punned with المواري به, i.e. the immediate meaning, which should be stated either before or after the punnable word.

The speaker \writer should provide a lexical requirement for the "punned with ـ immediate meaning" before the word which carries the pun.

Consider the following Quranic text:

Surah "Adh-Dhariyat", ayah 47.

و السماءَ بنيناهَا بأيدٍِ وانّا لموسِعونَ

We built the heavens by Our authority; and We are the Lord of power and expanse.

(3) Tawrriyah al-Mubayyinah (clarifying pun)

In order for this type of pun to work properly, the speaker $\backslash$ writer should provide a lexical requirement for the "punned to المواري عنه - remote meaning" before or after the word which carries the pun.

Surah "Al-Rahman", ayah 6.

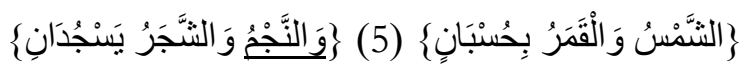

The sun and moon revolve to a computation; And the grasses and the trees bow (to Him) in adoration.

Tawriyyah al-Mubayyah (preparing pun)

In this type, the pun can only be considered if it came before or after a punnable word.

Surah "Al-Rahman", ayah 6.

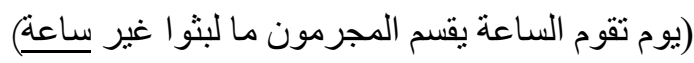

The day Resurrection is set the sinners will swear: "We did not tarry more than an hour (and cannot be guilty)."

\section{Methodology}

In this section, the researcher is discussing the theoretical framework of investigation, as well as the methodology, which consists primarily of description of the data collection and method of Analysis.

\section{Data Collection}

To achieve the purpose of the study a descriptive and comparative approach are selected. This study is focusing on the Holy Quran as the source text (ST) 
and its two English translations by Yusuf Ali (2014), Pickthall (1963) as target texts (TT). The data of several (Ayat) verses is randomly gathered from the Holy Quran and their equivalents in the selected English translations.

\section{Method of Analysis}

To achieve the objective of the study, several Ayat containing punning words from the holy Quran are selected, and analyzed based on Delabastita's strategies.

The correctness of some examples is considered by using the commentaries of Tafsir ibn Kathir, 759 AH and AI-Zamakhshari, 1972). Then, the same Ayat in the two English target texts is read to identify those parts of the texts, which corresponded to the original puns and underlined them. To conclude, conclusions are mapped up based on the data analysis.

\section{Data Analysis}

\section{Translation of Puns in Holy Quran}

Pun is one of the semantic and linguistic features of the Holy Quran.

A pun is a tricky use of a word or phrase, which has various different meanings that are closely interrelated, or of words with the same sound but different meanings.

The translator encounters obvious difficulty when tries to convey the intended meaning of the pun words because he/she will be confused by the various meanings and senses of these words. The Holy Quran features many punning words in its structure.

1- For instance, the word ūmmah (- أََُّة - people) has nine pun meanings. It can mean a period of time, as in surah Yusuf:

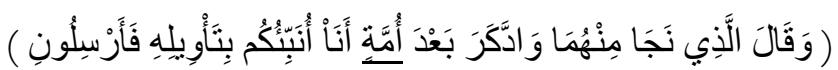

However, the man who had been released, one of the two (who had been in prison) and who now bethought him after (so long) a space of time, said: 'I will tell you the truth of its interpretation: send ye me (therefore)'. (Yusuf Ali's Translation) (Surah Yusuf 12:45).

Nevertheless, in some cases, the word ümmah refers to the leader of the people who teaches or guides the believers to the right path in their religion and life, as in surah al-Nahl: 


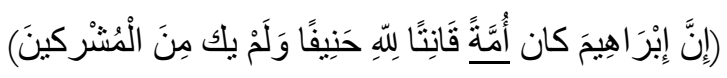

Abraham was indeed a model, devoutly obedient to Allah, (and) true in Faith, and he joined not gods with Allah. (Yusuf Ali's Translation) (Sura Al-Nahl 16:120).

Arberry (1964) translated this verse as follows: (Surely, Abraham was a nation obedient unto God, a man of pure faith and no idolater.) Arberry's translation is completely out of context and meaning. As the word (ummah - أمة) refers to man educated in the Islamic rules and who teaches these rules to the people, it does not refer to (nation). (Abobaker, Brakhw, Nordin, and Ismail, 2012).

Also, the word ( أمة - ummah) refers to a group of people who has passed away, as in the

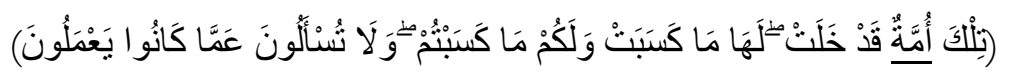

That was a people that hath passed away. They shall reap the fruit of what they did, and ye of what ye do! Of their merits there is no question in your case! (Yusuf Ali's Translation) (Sura Al-baqarah 2:134).

Those are a people who have passed away. Theirs is that which they earned, and yours is that which ye earn. And ye will not be asked of what they used to do. (Pickthall's Translation) (Sura Al-baqarah 2:134).

Also, the word ( أمة - ummah) refers to a religion or creed that some people follow, as in the

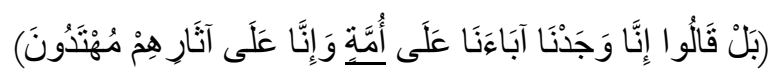

Nay! they say: "We found our fathers following a certain religion, and we do guide ourselves by their footsteps". (Yusuf Ali's Translation) (Sura Al-zukh'ruf 43:22).

Finally, in other punning meanings, the word (أمة - ummah) refers to a hell or inferno as in the

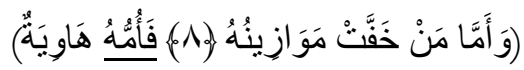

However, he whose balance (of good deeds) will be (found) light, Will have his home in a (bottomless) Pit. (Yusuf Ali's Translation) (Sura Al-qāri ah 101:8,9).

Nevertheless, as for him whose scales are light, A bereft and Hungry One will be his mother. (Pickthall's Translation) (Sura Al-qāri' ah 101:8,9).

Pickthall's translation is also out of context and meaningless. As the word (ummah - أمة refers to those their ends will be in the hell or inferno, it does not at all refer to (mother).

2- Also, the word religion (دين - Deen) has several different pun meanings. Commonly the word Deen refers to religion however, in the Quran it has different meaning. It can mean a Day of Judgment, as in surah Al-fātihah: 
(مَالِلكِ يَوْمِ الآدِينِ)

Master of the Day of Judgment. (Yusuf Ali's Translation) (Sura Al-fātiḥah 1:4)

Nevertheless, in some cases, the word Deen refers to the religion or creed, as in surah Al-fatihah:

$$
\text { (لكم دينكم ولي دين) }
$$

To you be your Way, and to me mine. (Yusuf Ali's Translation) (Sura Alkāfirūn 109:6) Ali's translation is completely out of context and meaning, due to he translated the word Deen as way.

Unto you your religion, and unto me my religion. (Pickthall's Translation) (Sura Al-kāfirūn 109:6).

\section{The Types of English Puns Produced By the Two Translators of Quran:}

According to Delabastita's (1993) typology, Pichthall has applied the strategy of pun to related rhetorical device through repeating the equivalent word. However, Yusuf Ali has used the strategy of pun-to-pun and replaced the original pun with a pun in the English. The pun produced in target text is called "homonymic" pun, which is the equivalent to pun called "Tawrriyah Mubayyinah" in the source text. Linguistically, Pichthall has succeeded to convey the rhetoric and semantic sense of the Arabic pun into English without changing the meaning.

Some Reasons for Misinterpreting the Meanings of Puns in the Holy Quran into English:

The translation of the Quran should not be subject to whims and individual wills, desires because one's translation that does not meet these standards will definitely contribute to distorting the image of the Quran and presenting it to the people with a distorted features, rudimentary phrase and rigid, does not give to the reader mind what the miraculous Quran does.

The researcher believes that these are some of the reasons:

I. The translator of the Quran is not from an Arabic origin, and /or his first tongue is not Arabic tongue.

II. The translator has a lack of or no expertise in translating the religious text. 
III. The translator is not familiar with several interpretations/ Tafsirs of the Quran.

IV. The translator does not have the proper skills or knowledge of the science of Quran, Haith and Sunnah.

V. The translator is not fluent in the target language (either Arabic or English)

VI. The task of translating the Quran is always made through individual attempts, which upsurges the likelihood of committing mistakes and errors.

\section{Conclusion}

This paper is a part of a $\mathrm{PhD}$ thesis on the translation of puns in the Holy Quran; therefore, the current study analysis is partially derived from the main thesis. It is understood that the incidence of the pun in the Quran produces a noteworthy challenge for the translators since numerous words in the Quranic verses are pun. Consequently, if the Quran translators are not aware of the factors that help them to capture the deep meaning, they will not be able to transfer the intended meaning effectively.

Finally, the above translations examined a generally tend to simplify the intricate linguistics and semantic relationships of the original and reduce its multiple structural possibilities by offering only one meaning of Ayat concerned. The study found that the translations do not always consider the deeper meaning of the word, and the loss of translation is a predominant fact in Qur'an translation. The methodology followed in this study can be applied to other words/terms in the Qur'an. The research can also go beyond word level to cover wider scopes and contexts within the Qur'anic text.

Consequently, the translator must depend on a number of dictionaries in both Arabic and English to determine the specific meaning of the words. The translator must also consult the various commentaries of the Quran to obtain the appropriate interpretation of the Quranic verses. The translator must have a long experience in religious text translation, and must be conversant with several interpretations of Quran also, has to be fluent in the target language. This study recommend that the translation of the Holy Quran should be conducted by a group of experts or a committee that includes experts in the language, culture, history and science of the Quran in order to do such heavy task accordingly. 


\section{References}

Abdul-Raof, H. (2006). Arabic Rhetoric: A Pragmatic Analysis. Routledge.

Al-Zamakhsharī, M. O. (1972). Tafsīr al-Kashshāf, Cairo: Halabī. Khalifa, Muhammad, Translation: Tried \&True?. 2005 [Online] http://www.cyberistan.org/islamic/translate.htm

Al Aqad, M., Arifin, A., Kadhim, K., \& Salleh, M. (2017). Translation of Selected Pun Words from the Holy Quran into English. Turkey, TOJET. (Special Issue for INTE 2017).

Ali, A. Y. (2003). The Meaning of the Holy Qur'an. New Edition with Revised Translation. Commentary, and Newly Compiled Index, 10th ed., Beltsville: Amana Publications.

Ali, A., Brakhw, M. A., Nordin, M. Z. F. B., \& ShaikIsmail, S. F. (2012). 2Some linguistic difficulties in translating the holy Quran from Arabic into English2. International Journal of Social Science and Humanity 2(6), 588-590.

Allaithy, A. (2013). Qur'anic Term Translation. A Semantic Study from Arabic Perspective, Antwerp: ATI-academic publications.

Delabastita, D. (1987). Translating Puns. Possibilities and Restraints. New Comparison, 3, 143-59.

Delabastita, D. (2004). 'Wordplay as a translation problem: a linguistic perspective', in Übersetzung, translation, traduction, ed. Harald Kittel et al., Berlin: Mouton de Gruyter, 600-606.

Delabastita, D. (1993). There's a Double Tongue: An Investigation into the Translation of Shakespeare's Wordplay, with Special Reference to Hamlet. Amsterdam: Rodopi.

Hijjo, N. F., \& Kadhim, K. A. (2017). 'The Analysis of Grammatical Shift in English-Arabic Translation of BBC Media News Text'. Language in India, V. $17(10)$.

[Online] http://www.languageinindia.com/oct2017/kaisnaelbbcnewstexttranslation1 .pdf

Pickthall, M. (1993). The meaning of the glorious Koran. New York, NY: Random House USA Inc.

Tayara, A. M. (2015). The Meaning of Nazala in the Holy Qur'an (Master thesis), American University of Sharjah.

\section{ARABIC REFERENCES:}

Al-Bukhturī:, W. (1972). Diwān al-Bukhturì; 5 vols. Edited by Hassān Kāmil alSayrāfì. Cairo: Dār al-Ma‘ārif. 
Al-Jawharī. (1956). Al-Lughah wa-l-baläghah al-'arabiyyah. Vol. 6. Beirut: Dār al'Ilm.

Al-Qazwinī (1904). Al-Talkhiṣ fì 'ulūm al-baläghah. Ed. 'Abd al-Raḥmān alBarqūqī. Beirut: Dār al-Kitāb al-'Arabī.

As-Ṣafadī (1979). Fadd al-kbitām 'an al-Tawriyyah wa-listikhdām. Ed. alMuḥammadī, 'Abd al-'Azīz al-'Ināwī. Cairo: al-Maktabah al-Azhariyyah li-1Turāth.

As-Șafadī (1987). Jinan al-jinās fì ‘ilm al-bādì. Beirut: Dār al-Kutub.

As-Safi, A.B. (2011). Translation theories, strategies and basic theoretical issue. Petra University. [Online] http://books.fledu.uz/wp-content/uploads/sites/4/ 2016/10/Translation-theories-strategies-and-basic-theoretical-issues.pdf

Ibn Fāris, A. (1328/1963). Al-Ṣähibì fi fiqh al-lugha wa-sunan al-'arab fì kalämihā, Beirut: Mu'assasat Badran li-l-Tibā'ah wa-l-Nashr.

Sadiq, S. (2010). A comparative study of four English translations of Surat Ad-Dukbiin on the semantic level. Newcastle: Cambridge Scholars Publishing. 